The Polish Journal of the Arts and Culture. New Series 12

(2/2020): 63-86 [ARTYKU‡]

DOI: $10.4467 / 24506249$ PJ.20.009.13448

\title{
Radziecki wysiłek kolonialny, czyli socrealizm i orientalizm. Uwagi na marginesach powieści Człowiek zmienia skórę Brunona Jasieńskiego
}

\author{
Kasper Pfeifer
}

\begin{abstract}
Streszczenie
Artykuł opisuje radziecki projekt kolonialny lat trzydziestych XX wieku. Na przykładzie socrealistycznej powieści Brunona Jasieńskiego Człowiek zmienia skórę, autor analizuje hegemoniczny dyskurs metropolii oraz rozmaite strategie jego aplikacji na terenie Centralnej Azji. Rozprawa skupia się na takich zagadnieniach, jak nadreprezentowane w utworze wątki radzieckiej mission civilisatrice, patriarchalne uwikłania kolonialnej dominacji Rosjan oraz władanie poprzez narzucanie obecności, czyli wypieranie lokalnej problematyki i przywłaszczanie/przekształcanie obcej geografii.
\end{abstract}

Słowa kluczowe: Bruno fasieński, postkolonializm, socrealizm, dekolonizacja, gender studies

Kasper PfeIfer, kierownik projektu NCN Preludium Estetyka jako polityka. Twórczość Brunona Jasieńskiego oraz laureat konkursu ETIUDA. Interesuje się poezją rewolucyjną, futuryzmem oraz historią ludową. Publikował m.in. w „Zagadnieniach Rodzajów Literackich”, „Wielogłosie”, „Praktyce Teoretycznej” i „Tekstach Drugich”. Autor książki poetyckiej adblock (Łódź 2019), nominowanej między innymi do Nagrody Poetyckiej Silesius.

E-MAIL: pfeifer.kacper@gmail.com 
Uznawana za pierwszorzędne dzieło prozy produkcyjnej wczesnosocrealistyczna powieść Jasieńskiego, oprócz skrupulatnego zrealizowania podstawowego założenia radzieckiej dydaktyki, w myśl której w ogniu kolektywnego wysiłku wykuwał się „nowy człowiek”, podejmuje istotną kwestię panowania Cesarstwa Rosyjskiego i państwa po niej dziedziczącego w Azji Środkowej (Kolesnikoff 1982, 97-98) ${ }^{1}$. O tym, że eksfuturysta sproblematyzował w swoim utworze pełne niuansów makro- i mikropraktyki władzy, wpływające na produkcję podmiotu kolonialnego, przekonujemy się już w jednej z sekwencji scen zawiązania akcji, w której amerykański inżynier Jim Clark na skutek Wielkiego Kryzysu trafia do Tadżyckiej SRR, by wziąć udział w budowie systemu irygacyjnego mającego przekształcić tę ziemię jałową w krainę urodzaju. Gdy Amerykanin udaje się na swoje pierwsze spotkanie z miejscowymi robotnikami, zatrzymuje go tłumaczka i członkini Komsomołu Mariam Połozowa:

Otworzył walizkę, wyjął notes, biały kolonialny kask i zamknąwszy walizkę włożył kask.

- Wie pan co? - usłyszał nad sobą głos Połozowej. Stała oparta o parapet. - Niech pan posłucha koleżeńskiej rady. Lepiej tego nie wkładać. Niech pan pozostawi ten kociołek w domu, lepsza będzie cyklistówka.

- Ale dlaczego? - zmieszał się Clark.

- To oczywiście drobiazg, lecz kolonialne kaski stanowią swoisty styl polityczny. Po tamtej stronie granicy, w Indiach, odróżniają one kolonizatora od niewolnika-tuziemca. U nas ten styl kłuje w oczy. My wszyscy nosimy tu tiubetejki ${ }^{2}$. [...] Niech się pan nie obraża. Jeżeli pan chce, może pan jechać w kasku. Chciałam tylko po przyjacielsku ustrzec pana przed niechętnymi spojrzeniami robotników. Przyzwyczaili się, że nasi inżynierowie i kierownicy nie wyróżniają się specjalnie strojem (Jasieński 1961, 85).

Słowa Połozowej demaskują podstawową sprzeczność radzieckiego projektu wewnętrznego kolonializmu oraz towarzyszącego mu dyskursu orientalistycznego (por. Hechter 1975; Etkind 2011). Wszak w tym wypadku - co w porównaniu z imperializmami francuskim i angielskim może jawić się jako bezprzykładne - władający nie chce być postrzegany jako ten, który włada.

${ }^{1}$ Praca naukowa finansowana ze środków Narodowego Centrum Nauki. Projekt nr 2018/29/N/HS2/oo791.

${ }^{2}$ Tiubetejka - niewielka, owalna lub kwadratowa czapeczka, często zdobiona bogatym haftem, tradycyjnie noszona przez mieszkańców Azji Centralnej. 
Słusznie, jak sądzę, budzi to skojarzenia z pojęciem mimikry kolonialnej Homiego Bhabhy, z tą jedynie niekonsekwencją, że, według badacza: „pragnienie zreformowanego, rozpoznawalnego Innego, jako podmiotu różnicy, który jest prawie taki sam, ale nie całkiem”, dotyczyło raczej podporządkowania usankcjonowanej przez centrum normie skolonizowanych, a nie - kolonizujących (Bhabha 2008b, 185). Na tej podstawie należałoby uznać, że radzieckie strategie dominowania, strukturyzowania i sprawowania władzy zakładały częściową przynajmniej akulturację lokalności, dążąc do utrzymania pozorów przezroczystości systemu panowania (Loring 2014, 81). Słowem, uwagę przykuwa tu próba ostentacyjnego rozmycia różnicy, a nie obwarowania jej znakiem jedynie pozornego zniesienia. Wszelkie symptomy negowania zadeklarowanej w ten sposób „równości” przedstawicieli centrum i „tuziemców-niewolników" w projekcie kolonialnym Stalina potępiano bezwzględnie jako „mocarstwowy szowinizm”, by posłużyć się słowami jednego z drugoplanowych bohaterów powieści ${ }^{3}$.

Jak wynika m.in. z badań Alexandra Morissona i Ewy Thompson, w przeciwieństwie do imperializmu zachodnioeuropejskiego rosyjska, a w szczególności radziecka, ekspansja kolonialna w Środkowej Azji nie szukały usprawiedliwienia w rasistowskim dyskursie różnicy, zamiast tego znajdując oparcie w stanowczym uprzywilejowaniu wszystkiego, co rosyjskie, bądź - po roku 1917 - proletariackie (Morisson 2006, 672). Należy dodać, że granice „rosyjskości”, a potem „proletariackości” wytyczano dosyć swobodnie, chętnie akceptując Innego, jeśli ten w zadowalający sposób wpisał się w charakterystyczną dla metropolii, uniwersalistyczną strukturę społeczną i tekstualną. W powieści Polaka - Jasieńskiego, wówczas już zasymilowanego użytkownika „wspólnego” języka rosyjskiego (sic!), ten sposób myślenia poświadczają takie postacie, jak zastępca kierownika, a później naczelnik wielkiej budowy Said Urtabajew (Uzbek) lub Kerim Nusreddinow (Tadżyk), przewodniczący Komsomołu. Dość powiedzieć, że w przedsięwzięciu kolonialnym Kraju Rad, na mocy podpisanej u zarania rewolucji przez Lenina i Stalina Deklaracji praw narodów Rosji (1917), wszystkie narodowości zamieszkujące imperium uznano oficjalnie za równe i autonomiczne, pod warunkiem zjednoczenia

3 Nadużywających władzy reprezentantów metropolii oskarżano zwykle w pokazowych procesach o szowinizm i rosyjski nacjonalizm, przekonując zarazem, że obecność Rosjan w Azji Środkowej nie znosi porównań z kolonializmem. Szowinizm to aberracja niektórych towarzyszy - argumentowano - a nie systemowe rozwiązanie czy narzucony model władania (Kassymbekova 2016, 126-127). Na temat krytyki szowinizmu w powieści Jasieńskiego zob. Jasieński 1961, 467 . 
wokół emblematycznego dla metropolii języka walki klas (Lenin i Stalin 1993, 66-67). Pod rządami Stalina znaczenie tożsamości narodowych w polityce imperium wzrosło. Produkcja podmiotów kolonialnych w republikach i państwach zależnych miała odtąd przebiegać zgodnie z paradygmatem „proletariackiego w treści, narodowego w formie" (Tlostnova 2012, 137-138; Keller 2020, 14). Wskutek tego, zdaniem badaczki Botakoz Kassymbekovej, trudno mówić o radzieckim kolonializmie jako o reżimie wspartym na takim zarządzaniu Innością, które praktykowano na przykład w brytyjskich Indiach, wskazanych zresztą przez Jasieńskiego jako z gruntu negatywny wzorzec. Zmierzano raczej do władania poza Innościami, pomimo kultur, które uznawano za konstrukty przejściowe, nieprzystające do utopistystycznej wizji przyszłości (por. Vaugham 1973, 97). Ponieważ odpowiedzią Związku Radzieckiego na imperializm krajów kapitalistycznych, które podbitymi terytoriami rządziły zwykle w aliansie z miejscowymi elitami, było wywłaszczenie peryferyjnej burżuazji, kolektywizacja i upaństwowienie środków produkcji, ów projekt - jeśli postrzegać go w zgodzie z oficjalnymi dekretami Komitetu Centralnego KPZR - w istocie mógł przedstawiać się jako program antykolonialny (Castillo 1997, 34; Thomas 2018, 72; Pianciola 2004, 144-147).

Misja cywilizacyjna Związku Radzieckiego przybrała w Azji Centralnej maskę troski o skuteczną kolektywizację oraz powodzenie inwestycji w gospodarkę wodną regionu. Oba przedsięwzięcia oraz ich społeczne skutki pełnią funkcję kręgosłupa, na którym wspiera się fabuła powieści Człowiek zmienia skórę4. W związku z powyższym, zamierzam zadać na marginesach tekstu Jasieńskiego kilka pytań o naturę radzieckiego kolonializmu i jego manifestacji w reprodukowanym przez centrum dyskursie policyjnym, czyli takim, który nie tylko „kontroluje i ogranicza podmiot, lecz, i to zakłada perspektywa biopolityczna, również pośrednio go współtworzy" (Andrzejewski 2019, 173). Czy wobec tego przedstawiony w utworze Tadżykistan stał się zaledwie sceną na której Rosjanie, biorąc w posiadanie pozbawione pamięci ziemie, odgrywali pierwszoplanową rolę w kolejnej „wielkiej” historii pisanej

4 Jak dotąd Człowiek zmienia skórę nie doczekał się zbyt wielu opracowań. Autorem pracy w całości poświęconej powieści jest Mateusz Kłagisz (Kłagisz 2014). Cały rozdział w swojej monografii poświęciła jej również Nina Kolesnikoff (Kolesnikoff 1982, 93-109). Pozostali badacze albo wspominają o utworze na marginesach swoich rozważań, traktując go jako kontekst bądź rodzaj argumentu dowodzącego - by użyć pojęcia Wojciecha Tomasika „nieliterackości” socrealizmu (Tomasik 2016, 13 i nast.), albo po prostu pomijają go w swoich analizach (Jaworski 2009; Krzychylkiewicz 2006). Poszukując tendencji orientalistycznych w socrealizmie, o powieści Jasieńskiego wspomina również Leonid Heller (Heller 2012, 9). 
z punktu widzenia zwycięzców, czy może przeciwnie, polski eksfuturysta odszedł w swojej powieści od tego rodzaju paternalistycznych systematyzacji? Czy rosyjskojęzyczni bohaterowie tej rosyjskojęzycznej powieści myślą i działają w powstałej w 1929 roku Tadżyckiej SSR przez pryzmat świadomości jej statusu republiki zależnej, czyli kolonii w rzeczy samej? (por. Thompson 2000, 33). Innymi słowy, zamierzam podjąć się poszukiwania śladów kolonialnej dominacji w tekście powieści Człowiek zmienia skórę oraz możliwych przemilczeń autora, biorącego czynny udział w grze imperium mającego w Azji Środkowej zarówno określone interesy, jak i konkretne strategie ich realizowania (Shore 2012, 150-151). By osiągnąć sprecyzowany cel, skupię się na analizie nadreprezentowanych w utworze wątkach radzieckiej mission civilisatrice, kolonialnej dominacji Rosjan i towarzyszącej jej polityce płci oraz zagadnieniu władania poprzez narzucanie obecności, to jest wypieranie rdzennej problematyki i przywłaszczanie/przekształcanie obcej geografii przez imperium.

Imperatyw „cywilizowania Innego”, jako praktyki rzekomo dekolonizującej Azję Środkową, stanął u podstaw imperialnego dyskursu Związku Radzieckiego już w pierwszym okresie jego istnienia (Teichmann 2007, 499-500). Pod tym pojęciem bolszewicy rozumieli przede wszystkim przełamanie dawnych kolonialnych uprzedzeń i hierarchii odziedziczonych po carskiej administracji oraz promocję emancypacji grup konsekwentnie wykluczanych przez przedrewolucyjną maszynerię panowania (Loring 2014, 8o-81). Za środek do celu uznano kolektywizację, która - oprócz przywiązania do ziemi lokalnych wspólnot nomadycznych - miała przynieść Tadżykistanowi „nowoczesne” metody produkcji rolniczej oraz uniezależnić gospodarczo młodą republikę (Kassymbekova 2016, 74). Ze względu na panujący $\mathrm{w}$ regionie klimat, moskiewskie władze zdecydowały o skoncentrowaniu środków produkcji środkowoazjatyckich republik na uprawie bawełny, co wymagało zbudowania na pustyni skomplikowanej i kosztownej sieci irygacyjnej (Teichmann 2016, 226). Jak z tego wynika, sukces opisanego przez Jasieńskiego przedsięwzięcia, nawiasem mówiąc, jednego ze sztandarowych projektów pierwszej pięciolatki (1928-1932), przedstawiał się jako podstawowy warunek powodzenia misji (de)kolonizacji przez modernizację, a w szerokim planie - ustanowienia komunistycznych, horyzontalnych społeczności w krajach Azji Centralnej (Beningsen 1969, 148). Ponadto, jak konkluduje historyk Christian Teichmann, w dolinie rzeki Wachsz, w której polski autor umieścił akcję powieści, owe wielkie projekty irygacyjne oraz towarzyszące 
im narracje były skrojone tak, by wspomagać pracę wyobrażania narodów oraz produkcję tego rodzaju nowej tożsamości pośród lokalnych plemion turko-tatarskich (Teichmann 2016, 227; por. Anderson 1997) ${ }^{5}$. Metropolia kładła więc nacisk na aspekt „posiadania” powstających konstrukcji, radziecką misję cywilizacyjną opisując jako pomocną dłoń podaną młodej republice przez Rosję - „starszego brata” (Laurelle 2009, 28). Nie umknęło to uwadze Jasieńskiego, który odniósł się do tej problematyki ustami inżyniera Clarka i tłumaczki Połozowej:

- Wiem na podstawie innych waszych budów, że Rosjanie umieją wykonać rzeczy niewykonalne - powiedział z galanterią Clark.

- Tu nie Rosja, lecz Tadżykistan, i budują nie Rosjanie, lecz Tadżycy; Rosjanie tylko pomagają Tadżykom (Jasieński 1961, 51).

Innymi słowy, Rosjanie i pozostali rzecznicy imperium wyglądający (prawie) jak Tadżycy, nie budują nowego, wspaniałego świata rękami Tadżyków, lecz ich jedynie wspierają, otaczając uważną opieką projekt-obietnicę końca zależności. Ze względu na przełomowy charakter tej „pomocy” ważną rolę w dyskursie metropolii odgrywało również uwydatnianie procesualności zmiany. Jak zauważył Mateusz Kłagisz, obraz Tadżykistanu odmalowany przez Jasieńskiego należałoby scharakteryzować przez zestawienie dwóch różnych czasowości oddzielonych momentem podporządkowania Azji Centralnej Związkowi Radzieckiemu: przedrewolucyjnej przeszłości oraz teraźniejszości, czyli etapu przejściowego zapowiadającego utopistyczną przyszłość (Kłagisz 2014, 18). Pierwszy z nich symbolizował zacofanie cywilizacyjne, wykluczenie mas ze sprawowania władzy i dominację patriarchatu; drugi - postęp, sprawiedliwość społeczną oraz zniszczenie zastanych hierarchii zapowiadające nadchodzącą równość.

W powieści Jasieńskiego dynamikę ujmowanej w ten sposób rewolucji po raz kolejny ilustruje rozmowa komsomołki z Amerykaninem. Clark, choć

5 Tłumaczyłoby to duży nakład, liczbę wznowień powieści Jasieńskiego oraz znaczenie, które władze w Moskwie przypisywały produkcji tekstów kultury towarzyszącej temu przedsięwzięciu. Do czasu oskarżenia Jasieńskiego o szpiegostwo w 1937, jego Człowiek zmienia skórę doczekał się aż siedmiu wznowień. Aby zapoznać się ze stanem prac, a później - opisać je zgodnie z hegemoniczną narracją metropolii - na przełomie lat 20. i 30. ubiegłego wieku Tadżykistan, oprócz Brunona Jasieńskiego, odwiedzali tacy znani pisarze jak choćby Leonid Leonow, Konstantin Paustowski czy Piotr Pawlenko. Zob. Holt 2015, 2013. Powieść Jasieńskiego doczekała się nawet dwóch ekranizacji: filmu z 1959 roku (reż. R. Perelshtein) oraz serialu z roku 1979 (reż. B. Kimyagarov). 
wówczas nie wyzbył się jeszcze uprzedzeń wobec radzieckiego eksperymentu (w drugiej części powieści staje się, oczywiście, przykładnym socjalistą), ponownie został zmuszony do złożenia broni wobec krytycznej efektywności argumentacji Połozowej:

- Nasze pokolenie, które zniszczyło społeczeństwo kapitalistyczne, by wejść w socjalistyczne, na razie zmienia skórę. Jest to masowy i chorobliwy proces. Zmienily się stosunki między ludźmi, między ludźmi a rzeczami, między ludźmi a państwem. Poszerzyła się skala każdej poszczególnej jednostki, stara skóra stosunków kapitalistycznych pękła. Zmieniamy ją na bardziej obszerną, w której łatwiej nam oddychać. Jest to dopiero pierwszy krok do tego społeczeństwa komunistycznego, w jakim człowiek zrzuci z siebie wreszcie jak skorupę wszelkie skóry warunków [narzuconych przez konstrukty kulturowe - K.P.], po raz pierwszy osiągając w całej rozciągłości swoją uległą atrofii indywidualność.

- To utopia. Trzeba by z początku zmienić naturę ludzką.

- A czyż my jej nie zmieniamy? - coraz bardziej zapalała się Połozowa. Policzki jej płonęły. - ... Czy nie na tym polega największe znaczenie naszej rewolucji? [...] To długi i trudny proces. Stara skóra tak bardzo przyrosła, że czasami trzeba ją odrywać wraz z mięsem (Jasieński 1961, 129).

Choć w tym wypadku uwagę zdaje się zwracać przede wszystkim zgrabna metafora procesu rewolucyjnego oraz towarzyszące jej retoryczne uniesienie Połozowej, to z perspektywy analizy praktyk kolonizatorskich Związku Radzieckiego powinniśmy zająć się przemilczeniami języka dominacji w podobnym stopniu, w jakim skupiamy się na jego funkcji ujarzmiającej. Chodzi mianowicie o, przelotne z pozoru, napomnienie na temat możliwych kosztów tytułowej zmiany skóry. Tę bowiem - mówi komsomołka - jeżeli zajdzie taka potrzeba, nie licząc się z konsekwencjami, należy „odrywać wraz z mięsem”. Jak sądzę, znakomicie implikuje to ograniczenia radzieckiego projektu (de)kolonizacji przez modernizację i modernizacji przez (de)kolonizację (Teichmann 2007, 501). Otóż, z uwagi na to, że socrealistyczna powieść Jasieńskiego musiała ex definitione wpisywać się w logikę radzieckiego dyskursu policyjnego, próżno w niej szukać jakiejkolwiek wzmianki na temat kosztów transformacji poniesionych przez młode republiki rad. Autor Stowa o fakubie Szeli nie stroni co prawda od opisów trudności i przeszkód, które napotykał na swojej drodze radziecki projekt modernizacji Tadżykistanu, jednakże zgodnie z poetyką prozy produkcyjnej - są to zawsze przeciwności przezwyciężone; bez znaczenia, czy mowa o kontrrewolucji, działalności sabotażystów, tradycyjnie zorientowanej miejscowej kulturze, czy antyradzieckim 
powstaniu basmaczy. Ostatnie, najpoważniejsze, spośród wymienionych, zagrożenie dla powodzenia całego przedsięwzięcia, znamiennie zostało ujęte przez Jasieńskiego jako sprzeciw w zasadzie nieznaczący i z góry skazany

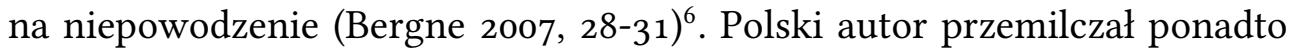
zarówno skutki kolektywizacji, która pochłonęła w Tadżykistanie, Uzbekistanie i Kazachstanie kilka milionów ofiar, jak i przymusowe przesiedlenia Rosjan i ludności turkijskiej, przeczące zadeklarowanej dekolonizacji regionu (Pianciola 2004; Kassymbekova 2011). Analizując przemilczenia radzieckiego dyskursu kolonialnego, należałoby dodać, że kolektywizacja i próby relokowania przemysłu na terytoria zależne od Moskwy, jakby wbrew emfazie, z jaką, w ramach uprzywilejowanego idiomu wypowiadali się przedstawiciele imperium, zamiast przynieść równość środkowoazjatyckim masom i anulować centro-peryferyjną logikę zależności, jedynie uwikłały je w nowe hierarchie, tworząc niesamodzielne i podporządkowane metropolii monokultury (Benningsen 1969, 149; Loring 2014, 85-94).

Wszak modernizacja, konsekwentnie przedstawiana przez Jasieńskiego jako warunek osiągnięcia przez peryferia zdefiniowanej przez centrum nowoczesności, w praktyce oznaczała niszczenie tradycyjnych struktur społecznych oraz kultury, zarówno materialnej, jak i niematerialnej, wytwarzanej przez te struktury. Rozumianemu w ten sposób „zapominaniu” tego, co przeszłe, towarzyszyło wzmożone zainteresowanie kolonizatora tak zwanymi „przenośnymi symbolami suwerenności”, przez co należałoby rozumieć programowe niszczenie świadectw środkowoazjatyckiej historii i tradycji heroicznej oraz „jałowienie” miejsc symbolizujących lokalne tożsamości. Pod tym względem, zauważa Ewa Thompson, władza radziecka niespecjalnie różniła się od poprzedzającej ją kolonialnej administracji caratu. Dlatego też takie artefakty, jak na przykład srebrny tron chanów Chiwy, możemy dziś podziwiać w muzeach Moskwy i Petersburga, a nie - Taszkientu czy Duszanbe (Thompson 2000, 179-180). To zaś, czego nie dało się wywieźć - meczety, nekropolie, medresy i obiekty kultu - niszczono, bądź zastępowano inwestycjami symbolizującymi nową władzę (Castillo 1997, 35; Keller 2020, 187).

W narracji Jasieńskiego znajdziemy odniesienia i do tej metody panowania. Polski autor ocenił ją pozytywnie, zaś skutki opresywnego podejścia

6 Basmactwo - wspierany przez dawnych feudałów oraz muzułmańskie duchowieństwo antybolszewicki ruch zbrojnie sprzeciwiający się radzieckiemu projektowi modernizacyjnemu. Największy rozkwit działalności basmaczy przypada na lata 20. XX wieku. 
do zdominowanej Inności potraktował raczej jako niedające się uniknąć powikłania radzieckiej misji, niż praktyki zubażające lokalną kulturę, co można zilustrować drugorzędnym z punktu widzenia fabuły przykładem świętej góry Kata-Tag. Z uwagi na pewne trudności projektowe budowniczy sieci irygacyjnej zmuszeni byli ją wysadzić. Wzbudziło to rzecz jasna sprzeciw tradycjonalistycznie zorientowanych autochtonów, dając Jasieńskiemu pretekst, by ważki problem gwałtownej i kosztownej modernizacji Azji Środkowej przedstawić w formie dobrze oswojonej przez tradycję literacką konwencji konfliktu pokoleń, gdzie starość kojarzona jest z tym co reakcyjne i zachowawcze, a młodość - rewolucyjne i postępowe:

- Krzeseł nie uznajesz? - uśmiechnął się Urtabajew [do ojca - K.P]. Jakim byłeś, takim pozostałeś. Cywilizacja europejska połamała sobie na tobie zęby. No cóż, niech tak będzie. Poczęstuję cię po azjatycku.

Zdjął ze ściany dywanik, rozesłał na podłodze, przyniósł imbryk, dwa placki, trochę smażonych moreli i sadowiąc się na drugim końcu dywanu przysunął starcowi poczęstunek. [...]

- Sporo świętych mazarów [mauzoleów - K.P.] zbezczeszczono - ze smutkiem pokiwał głową stary. - Nawet trudno odnaleźć miejsce. Byłem koło miasta Hisar, chciałem się pokłonić pewnemu mazarowi. [...] Zrównali z ziemią. Ponastawiali dokoła jurt, gołe dziewki w kusych izorach [spodniach - K.P.] i gołe chłopy rozwalone na świętym miejscu grzeją się na słońcu. Gdyby to byli tylko Rosjanie, to nie taki wstyd przed Bogiem, ale i muzułmanie chodzą w kusych szarawarach, obnoszą wszystko, czym ich Bóg obdarzył, dziewuchom na pokaz. Fuj!

- Na pewno trafiłeś do domu wypoczynkowego - roześmiał się Urtabajew. - Jak widzisz, i święte miejsce na coś się przydało: ludziom daje po pracy wypoczynek, a ty jeszcze zrzędzisz.

- Poszedłem pokłonić się świętej górze - ciągnął stary puszczając mimo uszu nieprzystojną replikę syna. - Dobrzy ludzie pomogli odnaleźć, bo i miejsca bym nie poznał. W dole maszyny na czterech łapach chodzą, górę gryzą, dymem plują, szczekają jak psy. Zapłakałem gorzkimi łzami [...] Pytam wierzących ludzi: „Komuż przeszkadzał święty mazar na górze?” I powiadają mi ludzie wierzący: „Muzułmanin pewien, Urtabajew Said, urodzony w Czubeku, maszyny tu przyprowadził i kazał im góry gryźć. [...] I pytają mnie ludzie „Powiadasz, wędrowcze, że jesteś z Czubeku, toś powinien go znać”. A ja odwróciłem się i skłamałem - niech mi Wszechmogący wybaczy! „Nie - powiadam - nie znałem w Czubeku takiego muzułmanina” (Jasieński 1961, 622-625). 
W dalszej części rozmowy na ojca Urtabajewa pada podejrzenie, że ten zaangażował się $\mathrm{w}$ organizację planowanego przez basmaczy ataku na ciągnącą się kilometrami konstrukcję kanału. W efekcie główny inżynier, reprezentant kompradorskiej, oddanej imperium elity, wydał rozkaz uwięzienia i przesłuchania podejrzanego. Biorąc pod uwagę, że niepokorny ojciec podczas swej pielgrzymki do miejsc kultu publicznie wyparł się syna, można powiedzieć, że zarówno na poziomie patriarchalnej normy, jak i eksploatowanej przez Jasieńskiego konwencji, dochodzi tu jak gdyby do symbolicznego zerwania, obosiecznego unieważnienia więzi ustanawiającej „rządy ojca”. Tym, co różni oba pokolenia, okazuje się zaś nie podejście do wewnętrznej logiki cywilizacyjnej misji kolonizatora, ale do trwania władzy radzieckiej. Sprzeciw wobec zdobywcy jawi się jednak jako skazany na niepowodzenie: oto bowiem znajdujący się na krawędzi życia starzec uosabiający przeszłość Azji Centralnej konfrontuje się tak z samą „,nowoczesnością”, jak i z przedstawicielem centrum, na którego skinienie „nieczyste”, szczekające jak psy koparki zdolne są niszczyć wszystko, co dotychczas wydawało się nieporuszone. To, co jednak, z punktu widzenia badacza tropiącego przemilczenia dyskursu kolonialnego wydaje się najdonioślejsze, to nie kolejne już przeciwstawienie nowoczesnego i obskuranckiego, lecz orientalistyczne ukazanie Azji Środkowej jako ziemi pozbawionej przeszłości. Ziemi, przed modernizacją trwającej w bierności i w bezruchu, jako świat natury, terytorium, które nie mogło nie poddać się przewadze „męskiej” kultury uosobionej przez Zachód (Said 2018, 79).

Prócz tego sprzeciw buntownika wzbudzają normy i praktyki towarzyszące seksualnej ekonomii panowania imperium. Jak argumentuje Monika Bobako, „kolonialna dominacja jest silnie ugenderowiona”, przez co należy rozumieć, że to właśnie sfera ciała, seksualność oraz przypisywane im znaczenia stają się obiektem wzmożonego zainteresowania kolonizatora, w równym stopniu służąc dyscyplinowaniu i podporządkowywaniu, co wyznaczaniu granic rasowych i etnicznych, oddzielających dominujących od zdominowanych (Bobako 2011, 83). Nie przypadkiem, jak się okazuje, w symbolice i ikonografii kolonialnej to właśnie kobiece ciało staje się przyczynkiem do opowieści o podbitym terytorium (Loomba 2005, 68-70). Wszak to kobiety w uniwersalizującej logice centrum „wyznaczają tak najbardziej sekretne sanktuaria rasy, kultury i narodu, jak i miejsca porowatych granic, przez które te konstrukty mogą być penetrowane” (Loomba 2005, 135). Ich pozycja 
w społeczeństwach skolonizowanych jest więc szczególnie wyeksponowana na działanie zdobywcy, a niezgodność systemu dystrybucji władzy między płciami z dominującą $\mathrm{w}$ metropolii normą spotyka się z posądzeniem kolonii o nienowoczesność albo barbarzyństwo (Mamhood 2017, 228). Stąd też wzmożona uwaga, jaką europejskie projekty kolonialne przykładały do kwestii „wyzwolenia” kobiet na terytoriach zależnych - ono bowiem, rozsadzając uświęcony lokalną tradycją podział ról płciowych, torowało drogę do zupełnej dominacji (Mohanty 1984; Amos i Parmar 1984). „Nawrócić kobietę, zyskać ją dla obcych wartości, wyrwać ją z ram jej statutu - powiada Frantz Fanon - znaczy jednocześnie zdobyć rzeczywistą władzę nad mężczyzną” (Fanon 1962, 13). Słowem, wyrwać kobietę z opresji „niecywilizowanego" patriarchatu i przenieść ją na łono cechującego się odmienną dynamiką „cywilizowanego” patriarchatu zachodniego, to znaczy zniszczyć lub - w najlepszym razie - nadwyrężyć swoiste dla danej lokalności modele władania (Bobako 2011, 96). W dyskursie produkowanym przez funkcjonariuszy radzieckiego imperium „podbój przez wyzwolenie” przybierał zwykle formę moralnej powinności towarzyszącej „cywilizowaniu” podbitej wspólnoty, w której „biali mężczyźni zmuszeni są ratować brązowe kobiety przed brązowymi mężczyznami” (Spivak 2011).

Niemniej, wracając do tekstu Jasieńskiego, niezgoda zbuntowanego starca wykroczyła poza samą tylko obawę o potencjalny rozpad lokalnych społeczności przez demontaż tożsamości kobiet i - w konsekwencji - symboliczną kastrację tadżyckich mężczyzn wiodącą do wykrystalizowania się na podporządkowanym terytorium nowej, pasywnej i „niefallicznej” normy męskości (Loomba 2005, 129; por. Karlsson 2015). Krytyka wyrażona przez ojca Urtabajewa zdaje się wszakże koncentrować na reformie obyczajów en soi, dotycząc przede wszystkim programowego niszczenia miejsc, które wydają się dla starca istotniejszymi nośnikami lokalnej tożsamości niż ciała skolonizowanych ${ }^{7}$.

Odmienny stosunek do kobiecego ciała, jako przedmiotu zainteresowania technologii imperialnej władzy, miał jego syn, inżynier Urtabajew, zrusyfikowany Uzbek, „prawie taki sam, ale nie biały”:

W przepełnionym tramwaju wciśnięto go między dwie masywne dziewoje. Dziewoje mocno pachniały mydłem toaletowym. Na następnym

7 Islamofobiczne uwikłania zachodniego feminizmu w imperialne projekty „cywilizowania dzikich” wyczerpująco omawia Monika Bobako (Bobako 2017). 
przystanku tramwaj rozładował się i Urtabajew usiadł na ławce obok drobnej kobiety w parandży [długiej, szczelnie zakrywającej ciało szaty, w tym wypadku - z maską - K.P.]. Barker [inny amerykański inżynier - K.P.] nazywał te kobiety „trędowatymi”. Zerknąwszy na sąsiadkę, Urtabajew po raz pierwszy pomyślał, że w tym żywym worku z czarną siatką zamiast twarzy rzeczywiście jest coś nasuwającego myśl o chorobie skórnej.

Naprzeciwko siedziała dziewczyna w małej niebieskiej czapeczce, z ostrzyżoną grzywką i puszystymi rzęsami. Takie dziewczęta widuje się tylko we śnie. Raz spojrzawszy chciałoby się patrzeć na nią godzinami nie odrywając oczu, nie mówić, nie dotykać, a właśnie patrzeć, jak się patrzy na rzecz prześliczną, kruchą i nietrwałą (Jasieński 1961, 335).

Urtubajew ocenia obie kobiety według kryterium wyznaczonego przez patriarchalną normę metropolii. Drobna postać w parandży przedstawia się mu jako ta, która kluczy wzdłuż granicy dzielącej dwie kultury i dwa systemy znaczeń. Wszak granica, jak pisze Homi Bhabha, poza tym, że oddziela, wyznacza także miejsce zetknięcia, niejednoznaczny obszar przenikania (Bhabha 2008a, 211). Z tego powodu uwagę przykuwa skojarzenie Inności z trądem, czyli z chorobą, której symptomy rozwijają się „na granicy”, czyli na powierzchni, nie wewnątrz organizmu. Chorobą która w zachodnim dyskursie maladycznym postrzegana jest zwykle jako kara, bądź znak wykluczenia ze wspólnoty (Sontag 2016, 73-86). W tym wypadku ta dezindywidualizująca i potencjalnie śmiertelna przypadłość zostaje użyta do opisu „żywego worka”, czyli muzułmanki nierezygnującej z lokalnej tożsamości i reprezentującej zwyczaj skazany przez kolonizatora na eliminację (Szubert 2008, 101). Gdyby, biorąc przykład z Urtabajewa, skierować uwagę na kobietę reprezentującą w tej scenie kulturę centrum, okaże się, że autor powieści w szczególny sposób uprzedmiotowił jej ciało. Jak czytamy: „chciałoby się patrzeć na nią godzinami [...] nie mówić, nie dotykać, a właśnie patrzeć, jak się patrzy na rzecz prześliczną, kruchą i nietrwałą". Potencjalna brzydota została tu antytetycznie skonfrontowana $\mathrm{z}$ jednoznacznością piękna: choroba - ze zdrowiem, a zaraźliwość trądu - z kruchością powabu.

Uczynienie z obu skolonizowanych kobiet przedmiotów oglądu jest zresztą jedną z praktyk podporządkowywania Innych patriarchalnej władzy kolonialnej. Otóż tym, który w tym wypadku patrzy, jest rzecznik imperium, tymi zaś, które spojrzenie przyjmują - podporządkowane. Zasymilowanapiękna wydaje się nie zdawać sobie sprawy z tego, że jest obserwowana. Nie można tego natomiast powiedzieć o „trędowatej”. Wszak, jak zauważył Fanon, „kobieta, która widzi, nie będąc widzianą, powoduje w Europejczyku 
uczucie frustracji. Nie ma żadnej wzajemności. Kobieta nie poddaje się, nie oddaje, nie wychodzi naprzeciw" (Fanon 1962, 19). Jako iż w europejskim patriarchacie kobiecość jest definiowana poprzez bycie poddawaną męskiemu spojrzeniu, ciało skryte staje na przeszkodzie widzeniu, a co za tym idzie uzyskaniu pozycji dominującej przez męski, wojerystyczny podmiot (Berger 2008, 47). Należałoby powiedzieć, że emancypacyjna propozycja kolonizatora jest w tym wypadku ofertą jedynie pozornego wyzwolenia, którego skutkiem jest nie równość - jak zwykło się twierdzić w krajach globalnej północy - ale proste przeniesienie podporządkowanych kobiet $\mathrm{z}$ jednego systemu patriarchatu $\mathrm{w}$ drugi. $\mathrm{Z}$ systemu dominacji, w którym podlegały mężczyznom reprezentującym lokalność, w zuniwersalizowany system, w którym władzę sprawuje mężczyzna-kolonizator (Bobako 2011, 213-237). Co ciekawe, Jasieński wydawał się dostrzegać zarówno wskazany splot patriarchatu i kolonializmu, jak i pozorność emancypacji uzyskanej dzięki reformie obyczajów:

Za Ikramem przyszła wdowa Zumrat, która już od śmierci męża nie zasłaniała twarzy przed obcymi i z żalem uskarżała się, że władza radziecka spóźniła się - ni mniej, ni więcej - tylko o trzydzieści lat: gdyby Zumrat wtedy odsłoniła twarz, to wszyscy mężczyźni z okolicznych kiszłaków [wsi - K.P.] zbiegliby się, aby ją zobaczyć, a teraz nikt się nawet nie obejrzy, jakby wcale nie odsłoniła twarzy (Jasieński 1961, 448-449).

Wdowa Zumrat, przewodnicząca dość istotnego dla przebiegu akcji kołchozu „Czerwony Październik”, choć nie ukrywa swojego poparcia dla wdrażanej przez centrum zmiany, sama zdecydowała się zrzucić zasłonę z chwilą śmierci męża, a więc dopiero w momencie, gdy okoliczności losu wyzwoliły ją z patriarchalnej zależności. Gdyby władza radziecka przyszła wcześniej, twierdzi Zumrat, „wszyscy mężczyźni [...] zbiegliby się, aby ją zobaczyć”. Otóż, okazuje się, że zawarta w odsłonięciu twarzy obietnica wyzwolenia z dominacji utkanej przez środkowoazjatycki patriarchat uprzywilejowuje te podmioty, które są widziane jako młode i piękne. Jest to, jak sądzę, miejsce osobliwego rozrzedzenia dyskursu, prowokujące, by zapytać: może wyrażona przez Zumrat pozytywna ocena radzieckiej walki z lokalną tradycją w jakiś sposób łączyła się z tym, że jej fizyczne piękno przeminęło, przynajmniej $\mathrm{w}$ pewnym stopniu uniezależniając ją od oceniającego, władczego i - ostatecznie - męskiego spojrzenia nie tylko kolonizatora, ale i członka wspólnoty „tuziemców”?

Przy okazji analizy seksualnej ekonomii radzieckiego kolonializmu warto powiedzieć o stosunku oficjalnych dyskursów imperialnych do problemu 
granicy dzielącej i łączącej kolonizatora/kolonizatorkę z Inną/Innym. W przeciwieństwie do tabuizacji związków międzyrasowych w koloniach francuskich i angielskich, relacja seksualna między przedstawicielką centrum oraz mężczyzną reprezentującym stłamszoną lokalność nie była w projekcie Stalina uznawana za transgresję zagrażającą tożsamości kolonizujących (por. Fanon 2020, 43-89).

W powieści Jasieńskiego ten model relacji został udokumentowany wątkiem zażyłości tłumaczki Połozowej i Kerima Nusreddinowa, przewodniczącego miejscowego Komsomołu. Związek Rosjanki z Tadżykiem jawi się jako, bądź co bądź, krótkotrwały, ale jednak rozkwit beztroskiej i „,zystej” miłości. Autor uwypukla spoiwo tego związku, czyli stachanowskie oddanie budowie przyszłego, wspaniałego domu dla „radzieckiego nowego człowieka”, ignorując zupełnie etniczność Kerima, czy mogący jej towarzyszyć imperatyw transgresji. Teza Ani Loomby, mówiąca, że kolonialna władza wyraża się w posiadaniu zdominowanej Innej przez białego mężczyznę, kolonialne lęki natomiast - w stosunku kobiety reprezentującej europejskość z mężczyzną wywodzącym z kolonii nie znajduje więc, według mnie, zastosowania do opisu zainteresowania władz ZSRR seksualnością w azjatyckich peryferiach (Loomba 2005, 138-139). Relacje zawiązywane przez reprezentantki metropolii z mężczyznami wywodzącymi się z kolonii, dopóki zachodziły na płaszczyźnie wytyczonej przez diatryby radzieckiej mission civilisatrice, nie spotykały się ze sprzeciwem. Na podstawie sposobu przedstawiania w powieści Jasieńskiego tradycyjnych tadżyckich społeczności można natomiast podejrzewać, że związek Połozowej i Nusreddinowa nie zostałby oceniony pozytywnie, gdyby ten drugi - miast marzyć o modernizacji Tadżykistanu okopał się na stanowisku poparcia dla ortodoksyjnego islamu i przedrewolucyjnych urządzeń wiedzy/władzy (Keller 2001, 141). Wówczas jednak napiętnowanie tej relacji wiązałoby się raczej z potencjalnymi powiązaniami Tadżyka z basmactwem niż z nieoswojoną przez kolonizatora etnicznością Nusreddinowa. Należy dodać, że relacja Połozowej z Tadżykiem nie jest jedynym związkiem Europejki z mężczyzną pochodzącym z kolonii, o którym można przeczytać na kartach Człowiek zmienia skórę. Podobną dynamiką cechuje się romans Uzbeka Urtabajewa z Rosjanką Walentyną Sinicyną. Jednak również i w tym wypadku konsensus wyznaczony przez kolonizatora nie wysuwa wobec niego zastrzeżeń, dopóty, dopóki pozostaje osadzony na fundamentach zaprojektowanych przez radziecki uniwersalizm. Nie rasa zatem, a stopień oddania imperium warunkował podejście do różnicy w projekcie kolonialnym Stalina. 
Zmierzając ku końcowi, przyjrzyjmy się obszernemu, co prawda, lecz opalizującemu w znaczenia fragmentowi relacjonującemu wizytę Sinicyny w Stalinabadzie:

Miasto, którego nie widziała od zeszłego roku, a znała w okresie jego niedawnego niemowlęctwa jako duży, rozrzucony kiszłak, okrzepło w tym roku, zmężniało i przemawiało już basem sygnałów autobusowych. [...] Poprzez soczewkę wspomnień, jak na zdjęciu rentgenowskim, wzrok jej rozróżniał przez ciało nowego miasta kościec znanego kiszłaku, jakim zastała go po raz pierwszy przed sześciu laty. Wtedy ciągnął się tu step pocięty zakurzonymi drogami. [...] Dziś, jak wypłowiała czapka frygijska, trzepotał tu umieszczony na żerdzi proporczyk lotniska. Dziś [...] wzdymał się jak blizna tor kolejowy i w nocy, strasząc szakale, przeciągle wyły lokomotywy. Dziś zakurzone bezimienne drogi z obydwu stron obrosły domami [...] Jeszcze przed trzema laty drogi usiłowały się bronić. Wiercily się pod kołami arb [dwukołowych wozów - K.P.], wybojami bodły chłodnice samochodów, łamały resory i koła [...] Wówczas w sukurs miastu z dalekiej północy przyjechali brukarze. [...] Każdej wiosny miasto obrastało lasem rusztowań. Pod jesień lasy wyrąbywano, odsłaniając nową dzielnicę, która wyrosła przez lato. [...] Sinicyna przecięła ulicę i [...] wyszła na wielki plac. W rogu planu na spiżowym postumencie stał spiżowy Lenin i ręką wskazywał na Wschód. [...] Za placem główna ulica zwężała się i przechodziła w stary bazar wzdęty na skrajach drogi drewnianym chaosem lepianek i straganów [...] Nad ulicą [bazaru - K.P.] wisiał ckliwo-korzenny zapach pieprzu, cebuli, baraniny, a syczenie roztopionego tłuszczu mieszało się jak syk żmii z powolną gardłową mową przechodniów [...] Była to tak zwana stara Azja, ta, którą przede wszystkim przychodzili oglądać przyjezdni, spragnieni zapoznania się z prawdziwym Wschodem. [...] Była to ta stara Azja napierająca na nowe miasto. Szła stamtąd, z krańców, główną ulicą na spotkanie napierających na nią białych domów, pewna i niezniszczalna, tarasując ulicę dusznymi lepiankami, i spode łba patrzyła na brukowaną perspektywę ciągnącej się po tamtej stronie placu zielonej alei. Między nią a nowym miastem stał Lenin ze spiżu. Tak było w zeszłym roku. W tym roku Sinicyna minąwszy plac aż krzyknęła - bazaru nie było! [...] żałowała skasowanego bazaru. Pomyślała, że tak właśnie rok za rokiem znika stara Azja. Wkrótce cały ten kraj [ZSRR K.P.] na przekór geografii werżnie się w ląd azjatycki jak chciwa macka Europy. Żądał tego socjalizm i chociaż Sinicyna nie wątpiła w słuszność tego żądania, żal jej było tego startego kolorowego pyłku, żal swoistości, której jedynymi przechowalniami pozostaną wówczas, jak jej się zdawało, muzea etnograficzne (Jasieński 1961, 258-262). 
Z uwagi na to, że nie istnieje coś takiego jak neutralna przestrzeń dająca odpór kryterium własności, należałoby przemyśleć te strategie jej przywłaszczania, hierarchizowania i wyobrażania, spośród których na pierwszy plan wysuwa się gest nazywania. Kolonizatorska kartografia, twierdzi Graham Huggan, jest wszakże narracją zmierzającą po pierwsze do produkcji znaczeń zaspokajających doraźne potrzeby zdobywcy, a po drugie do ich utrwalenia jako pozornie przeźroczystych symboli dominacji (Huggan 1991, 116-131). Choć więc mapę interpretuje się zwykle jako nieuwikłany w pole władzy system reprezentacji przestrzeni, to $\mathrm{w}$ istocie okazuje się ona jej drobiazgowo wyreżyserowaną projekcją (Harley 2002, 51-81). Słowem, zarówno arbitralne wyznaczanie granic, nazywanie (kołchoz „Czerwony Październik”, stolica Tadżykistanu Stalinabad), wymazywanie z mapy miejsc-przekaźników tożsamości (mauzolea, wysadzona przy okazji budowy kanału góra Kata-Tag) i zastępowanie ich przez konstrukcje symbolizujące system panowania metropolii (siedziby instytucji) służyły temu, by skolonizowany podmiot sam zaczął postrzegać się jako Inny (Spivak 1985, 254). Czynność nazywania czy zastępowania nazw działających przed podbojem sprawia ponadto, że przeszłość sprzed kolonizacji wydaje się jak gdyby niemożliwa do pomyślenia. Walentyna Sinicyna, odwiedzając Stalinabad, myśli i zachowuje się, jakby znała stolicę Tadżykistanu „od niemowlęctwa”, zapominając, bądź starając się nie pamiętać, że miasto istniało jako niewielka, ale ważna dla regionu osada handlowa na długo przed powstaniem Tadżyckiej SRR. Po raz kolejny środkowoazjatycka kolonia traktowana jest przez bohaterkę reprezentującą kolonialny reżim jako ziemia pozbawiona historii, „odkrywana” przez reprezentujących metropolię Rosjan i nie-Rosjan w sposób, który za Edwardem Saidem powinniśmy nazwać „ujarzmianiem i stwarzaniem Orientu” (Said 2018, 29).

Przed rewolucją Stalinabad, według Sinicyny, miał odznaczać się „niedorozwojem”, dziś, to jest dzięki nowoczesności przyniesionej do Tadżykistanu na bagnetach Armii Czerwonej, wybrukowane, zelektryfikowane i skomunikowane z metropolią miasto rozwija się dynamicznie, a tam, gdzie niegdyś był step, teraz, niby czapka frygijska, jeden ze znaków Wielkiej Rewolucji, rozpościerają się budynki lotniska. Po raz kolejny w powieści Jasieńskiego z opisu wyłania się obraz starcia starego z nowym. Po raz kolejny również, tak zwana „stara Azja” ustępuje pod naporem zdobywcy, a racjonalna męskość Zachodu, wyłaniająca się chociażby z aktu planowania przestrzennego, zwycięża z chaotycznym, sfeminizowanym Orientem, reprezentowanym 
przez historyczny rdzeń niegdysiejszego Duszanbe - gęsty, zatłoczony i wonny bazar, jeden z podstawowych symboli zorientalizowanej „egzotyki” (Castillo 1997, 42-44). „Miasto kolonizatora to miasto kamienia i stali [...] Miasto skolonizowane, miasto tubylcze, to miasto czarne [...] To świat zagęszczony, człowiek na człowieku, lepianka na lepiance [...] miasto skulone, [...] miasto brudasów” (Fanon 1985, 22). Dominantą tej nowej organizacji przestrzeni kolonizator uczynił „spiżowego Lenina”. Jego wieloznaczna obecność czytelnie obnaża podstawową sprzeczność radzieckiego projektu kolonialnego. Wszak to, że pomnik stoi w miejscu, w którym stare łączy się z nowym, a jego twarz zwraca się ku Wschodowi, z jednej strony pozwala się odczytywać jako wskazanie jednokierunkowej transmisji „nowoczesności”, z drugiej zaś daje podstawę, by wykazać, że sposób, w jak spiżowy (a więc i wiecznotrwały) Lenin dzieli starą i nową Azję jest symptomatyczny dla wszystkich europejskich dyskursów kolonialnych. Wykonywany przez upamiętnioną postać gest wskazania w stronę terytorium inkorporowanego do imperium należałoby odczytać jako gest towarzyszący podbojowi, gest, który znamy na przykład z pomników „odkrywców”: Krzysztofa Kolumba w Barcelonie, Henry'ego Mortona Stanleya w Kisangani (niegdyś - Stanleyville); oraz zwycięzców: Jana Sobieskiego w Gdańsku, czy wskazującej w stronę morza królowej Wiktorii w Southend (Aldrich 2012, 1-15).

Reasumując, poświęćmy kilka słów temu, co dziś nazwalibyśmy stosunkiem Jasieńskiego do orientalizmu i dyskursów orientalizujących. Jak się okazuje, podobnie jak kilka dekad później uczynił to Edward Said, autor Stowa o fakubie Szeli surowej ocenie poddał tego rodzaju strategię sprawowania władzy nad Orientem (Said 2018, 29). W Człowiek zmienia skórę afirmatywne podejście do przedsięwzięcia orientalizowania Tadżykistanu zostało przez Jasieńskiego zinstrumentalizowane dla celów charakterystyki bohaterów negatywnych, czyli wrogów klasowych, kontrrewolucjonistów itd., bądź - jak w przypadku generała Millera - agentów obcego imperium. Ukazawszy funkcjonariusza brytyjskiego wywiadu, który z uznaniem smakuje encyklopedię Azji Środkowej, odnajdując w niej samopotwierdzenie zachodniej dominacji, ostrze krytyki Jasieńskiego zdecydowanie mierzy w to, co rozumiemy pod nazwą wytwarzanej przez imperium scjentystycznej „obiektywności”:

Bucharczyk, jak każdy Azjata, jest niewykształcony, brudny, kłamliwy i pozbawiony, dzięki systemowi wschodniego rządzenia, wschodnich praw i obyczajów oraz, dzięki azjatyckiemu sposobowi myślenia, jasnego zrozumienia prawa i praworządności, a w gruncie rzeczy jest tym samym stepowym 
Kirgizem, tylko nie nomadem, lecz osiadłym chłopem, który nabył pewną zewnętrzną ogładę obywatelskości i czysto azjatycki spryt...

(Jasieński 1961, 392)

Co ciekawe, autor rzetelnie wskazał w przypisie na źródło powyższego passusu: „Memoriał Rosyjskiego Imp. Tow. Geograficznego” z 1855 roku, eksponując tym samym paralele między kolonializmem przedradzieckim a uciskiem towarzyszącym imperializmom krajów kapitalistycznych (por. Kassymbekova 2016, 76). I tym razem jednak obcujemy z wewnętrzną sprzecznością charakteryzującą radziecką obecność w Azji Centralnej. Niechęć do orientalizowania peryferiów, tak często deklarowana w oficjalnych radzieckich odezwach, dokumentach i ustawach, choć rodziła pozornie przezroczysty i prorównościowy dyskurs władzy, nie była w stanie ustrzec rzecznika imperium - Jasieńskiego przed takim ukazaniem Azji, które nie wyrażałoby się poprzez i dzięki wyobraźni europejskiej. Wszak określenia takie Azja i „azjatyckość” były w owym okresie traktowane przez rosyjskojęzyczne centrum jako określenia zacofania, stosowane tak do opisu kondycji nienowoczesnych peryferii, jak i na przykład rosyjskich chłopów, których w ośrodku władzy postrzegano jako brudnych, pasywnych i pozbawionych świadomości klasowej (Straeten 2019, 6oo; Bonnett 2004, 47-49). „Postęp zmusił Rosję do porzucenia przez nią jej zacofania i azjatyckości” - pisał Trocki w wydanej na wygnaniu Historii rewolucji rosyjskiej, dowodząc tym zarówno uprzywilejowania imperialnego centrum, jak i sprzężenia dominujących urządzeń radzieckiej wiedzy/władzy z dyskursem orientalistycznym (Trotsky 2000, 284).

Jak można było zaobserwować chociażby przy okazji wizyty Sinicyny w Stalinabardzie, również Człowiek zmienia skórę nie jest wolny od tego rodzaju napięć. Uwyraźniają się one najsilniej nie w miejscach przemilczeń czy osobliwych pęknięć na powierzchni (de)kolonizującego dyskursu strukturyzującego utwór, lecz w scenie zamykającej akcję powieści - tam też orientalistyczny wizerunek Azji został wyrażony explicite. Otóż, zgodnie z wymaganiami klasycznie skonstruowanej akcji, ze względu na atak basmaczy sukces rosyjsko-tadżyckiej budowy stał pod znakiem zapytania do ostatnich stron powieści. Z perspektywy budowniczych czarnym scenariuszem wydawała się jednak potencjalna kompromitacja w oczach zachodnioeuropejskich dziennikarzy, a nie - jak można by się spodziewać - przesunięcie terminu uroczystego otwarcia śluz. Ostatecznie, choć partyzantom udało się doprowadzić do zniszczenia tam i zalania doliny Kata-Tagu, dzielni radzieccy inżynierowie w ciągu nocy opanowali kryzys i powstrzymali spustoszenie, by 
następnego ranka, zgodnie z planem, zaprezentować zagranicznym wizytatorom efekty swego wielomiesięcznego trudu:

Morozow przesunął ręką po czole.

Sinicyn patrzył gdzieś w bok.

- No, jednym słowem, wodę zaraz puszczą... A oto, zdaje się, i goście wskazał na zbliżający się sznur samochodów. - No cóż, witaj gości. Mówić im nie warto. Po co wzniecać panikę. Pomyślą, że u nas tu rzeczywiście dzika Azja. [...]

- Dzień dobry panie Morozow! - przed nim stał schludnie wygolony belgijski profesor i uśmiechał się z wyrzutem. - A pan o nas całkiem zapomniał.

- Ach, skądże! - zakrzątnął się Morozow. Chciał się uśmiechnąć, ale mu się nie udało. - Po prostu, mieliśmy tu małe zamieszanie - rozłożył bezradnie ręce. - W nocy zapodziały się gdzieś klucze od kół sterowych i nie mogliśmy z samego rana otworzyć śluzy. Ale teraz jest wszystko w porządku. Ano, właśnie, już płynie woda! (Jasieński 1961, 677-688)

Słowem, sukces radzieckich inżynierów polega więc na tym, że udało im się oddalić ryzyko oskarżenia o „azjatyckość”.

Mając na uwadze powyższe rozpoznania, powinniśmy potraktować powieść Jasieńskiego jako probierz, ujawniający niekonsekwencje radzieckiego projektu kolonialnego oraz wpisane weń imperialne interesy rosyjskojęzycznego centrum. Dyskurs towarzyszący realizowaniu imperialnych ambicji Kraju Rad należałoby uważać raczej za pragmatyczną strategię, mającą na celu podporządkowanie Innego, niż za koncyliacyjne oddziaływanie na środkowoazjatyckie peryferia, które - zgodnie z deklaracjami Moskwy niosłoby jakąkolwiek szansę na dekolonizację i emancypację zdominowanych podmiotów. Wszak preludium radzieckiej obecności w Azji Środkowej nie różniło się znacząco od wyprawy Napoleona do Egiptu, podczas której francuskiej armii towarzyszył zastęp uczonych i tak zwanych ludzi pisma, mających obejrzeć, opisać i zinterpretować Orient (Rachmonova-Schwarz 2010, 12; Said 2018, 106-127). W tym kluczu, jak sądzę, należy czytać również powieść Jasieńskiego, uczestnika podobnej „wyprawy”, który w nagrodę za swój utwór został członkiem Komitetu Centralnego Komunistycznej Partii (de)kolonizowanego Tadżykistanu, a jego powieść - lekturą w tamtejszych

8 Warto dodać, że w okresie rządów Stalina, termin „azjatyckiego sposobu produkcji” wyszedł z użytku w oficjalnym radzieckim marksizmie, gdyż uwypuklał jego wewnętrzne sprzeczności oraz niezgodność z filozofią samego Marksa (Kołakowski 2009, 351-352). 
szkołach (Shore 2012, 150; Jaworski 2009, 214; por. Heller 2012, 9). Człowiek zmienia skórę bez wątpienia reprezentuje więc tę tradycję myślenia, w której „to Europa wyraża Orient” (Said 2018, 88).

\section{Bibliografia}

Aldrich, Robert. 2012. „Commemorating Colonialism in a Post-Colonial World”. E-rea. Revue Électronique d'Études sur le Monde Anglophone, nr 10.1.

Amos, Valerie i Pramar, Pratibha. 1984. „Challenging Imperial Feminism”. Feminist Reviev: $\mathrm{nr} 17$.

Anderson, Benedict. 1997. Wspólnoty wobrażone: rozważania o źródłach $i$ rozprzestrzenianiu się nacjonalizmu. Tłum. S. Amsterdamski. Kraków: Znak.

Andrzejewski, Łukasz. 2019. Zobaczyć to, co polityczne. Filozofia politycznej postrzegalności wedtug Jaquesa Rancière’a. Kraków: Universitas.

Bennigsen, Alexandre. 1969. „Colonization and Decolonization in the Soviet Union”. Journal of Contemporary History, $\mathrm{nr} 1$.

Berger, John. 2008. Ways of Seeing. London: Penguin Classics.

Bergne, Paul. 2007. The Birth of Tajikistan. National Identity and the Origins of the Republic, London-New York: I.B. Tauris.

Bhabha, Homi. 2008a. „DyssemiNacja. Czas, narracja i marginesy współczesnego narodu”. Tłum. T. Dobrogoszcz. Literatura na Świecie, nr 1-2.

Bhabha, Homi. 2008b. „Mimikra i ludzie. O dwuznaczności dyskursu kolonialnego". Tłum. T. Dobrogoszcz. Literatura na Świecie, nr 1-2.

Bobako, Monika. 2011. „Płeć, rasa, seksualność w kolonialnych ekonomiach władzy”. Nowa Krytyka, nr 26-27.

Bobako, Monika. 2017. Islamofobia jako technologia wtadzy. Studium z antropologii politycznej. Kraków: Universitas.

Bonnett, Alastair. 2004. The Idea of the West: Culure, Politics and History. New York: Red Globe Press.

Castillo, Greg. 1997. „Soviet Orientalism: Socialist Realism and Built Tradition”. Traditional Dwellings and Settlements Review, $\mathrm{nr} 2$.

Etkind, Alexander. 2011. Internal Colonization. Russia's Imperial Experience, London: Polity.

Fanon, Frantz. 1962. Algieria zrzuca zasłonę. Tłum. Z. Szymański. Warszawa: Iskry. 
Fanon, Frantz. 2008. Black Skins, White Masks, trans. C.L. Markmann. London: Pluto.

Harley, John Brian. 2002. „Maps, Knowledge and Power”. In The New Nature of Maps: Essays in the History of Cartography, Baltimore and London: The John Hopkins University Press.

Hechter. Michael. 1975. Internal Colonialism. The Celtic Fringe in British National Development, 1536-1966, Berkeley: University of California Press.

Heller, Leonid. 2012. „Décrire les exotismes : quelques propositions”. Études de lettres, $\mathrm{nr} 2-3$.

Holt, Katherine. 2015. „Performing as Soviet Central Asia's Source Texts: Lahuti and Džambul in Moscow, 1935-1936". Cahiers d'Asie centrale, nr 2.

Huggan, Graham, 1991. „Decolonizing the Map: Post-Colonialism, Post-Structuralism and the Cartographic Connetion". In Past the Last Post: Theorizing Post-Colonialism and Post-Modernism, ed. I. Adam, H. Tiffin. New York-London: University of Calgary Press.

Jasieński, Bruno. 1961. Człowiek zmienia skórę. Tłum. J. Brzęczkowski. Warszawa: Czytelnik.

Jaworski, Krzysztof. 2009. Dandys. Stowo o Brunonie Jasieńskim. Warszawa: Iskry.

Kalrsson, Gunnar. 2015. „Męskość jako projekt: kilka uwag psychoanalitycznych”. Teksty Drugie, nr 2.

Kassymbekova, Botakoz. 2011. „Humans as teritory: forced resettlement and the making of Soviet Tajikistan, 1920-38”. Central Asian Survey, nr 3-4.

Kassymbekova, Botakoz. 2016. Despite Cultures. Early Soviet Rule in Tajikistan. Pittsburgh: University of Pittsburgh Press.

Keller, Shoshana. 2001. To Moscow, not Mekka. The Soviet Campaign Against Islam in Central Asia, 1917-1941, London: Praeger.

Keller, Soshana. 2020. Russia and Central Asia: Coexistence, Conquest, Convergence, Toronto: University of Toronto Press.

Kłagisz, Mateusz. 2014. „Podwójny portret Tadżykistanu w powieści Brunona Jasieńskiego »Człowiek zmienia skórę«”. Przegląd Orientalistycz$n y, \mathrm{nr} 1$.

Kołakowski, Leszek. 2009. Główne nurty marksizmu, t. 1. Warszawa: Wydawnictwo Naukowe PWN.

Kolesnikoff, Nina. 1982. Bruno Jasieński. His Evolution from Futurism to Socialist Realism. Waterloo: Wilfrid Laurier University Press. 
Krzychylkiewicz, Agata. 2006. The Grotesque in the Works of Bruno Jasieński. Bern: Peter Lang

Laruelle, Marlène. 2009. „Le paradigme du colonialisme en Asie centrale postsoviétique", L'Homme \& la Société, $\mathrm{nr} 4$.

Lenin, Vladimir and Stalin, Joseph. 1993. „Declaration of the Rights of the Peoples of Russia”. In A Documentary History of Communism in Russia. From Lenin to Gorbachev, ed. R.V. Daniels, Hanover and London: University of Vermont Press.

Loomba, Ania. 2005. Colonialism/Postcolonialism. London-New York: Routledge.

Loring, Benjamin H. 2014. „Colonizers with Party Cards: Soviet Interlan Colonialism in Central Asia, 1917-39”. Kritika: Explorations in Russian and Eurasian History, $\mathrm{nr} 1$.

Mahmood, Saba. 2017. „Religia, feminizm i imperium: nowe ambasadorki islamofobii”. Tłum. J. Bednarek. Praktyka Teoretyczna, nr 4.

Morisson Alexander. 2006. „Russian Rule in Turkestan and the Example of British India, c. 1860-1917”. The Slavonic and East European Review, nr 4 .

Pianciola, Niccolò. 2004. „Famine in the Steppe. The collectivization of agriculture and the Jazak herdsmen 1928-1934". Cahiers du monde russe, nr 102.

Pianciola, Niccolò. 2004. „Famine in the Steppe. The Collectivization of Agriculture and the Kazak Herdsmen, 1928-1934", Cahiers du Monde russe, nr $1-2$.

Rachmonova-Schwarz, Delia. 2010. „Migrations During the Soviet Period and in the Early Years of USSR's Dissolution: A Focus on Central Asia”. Revue Européenne des Migrations Internationales, nr 3.

Said, Edward. 2018. Orientalizm. Tłum. M. Wyrwas-Wiśniewska. Poznań: Zysk i s-ka.

Shore, Marci. 2012. Kawior i popiót. Życie i śmierć pokolenia oczarowanych i rozczarowanych marksizmem. Tłum. M. Szuster. Warszawa: Świat Książki.

Sontag, Susan. 2016. „Choroba jako metafora”. W Choroba jako metafora. AIDS i jego metafory, tłum. J. Anders. Kraków: Karakter.

Spivak, Gayatri Chakravorty. 1985. „The Rani of Sirmur: An Essay in Reading the Archives". History and Theory, nr 3.

Spivak, Gayatri Chakravorty. 2011. „Czy podporządkowani inni mogą przemówić?”. Tłum. E. Majewska. Krytyka Polityczna, nr 24-25. 
Straeten van der, Jonas. 2019. „Borderlands of Industrial Modernity. Explorations into the History of Technology in Central Asia, 1850-2000”. Technology and Culture, $\mathrm{nr} 3$.

Szubert, Mateusz. 2008. „Gruźlica w dyskursie maladycznym”. Postscriptum Polonistyczne", nr 2.

Teichmann, Christian. 2007. „Canals, cotton, and the limits of de-colonization in Soviet Uzbekistan, 1924-1941”. Central Asian Survey, nr 4.

Teichmann, Christian. 2016. „Wildscapes in Ballyhooland: Shock construction, Soviet colonization, and Stalinist governance". Cahiers du Monde russe, $\mathrm{nr} 1$.

Thomas, Alun. 2018. Nomads and Soviet Rule: Central Asia under Lenin and Stalin, London - New York" I.B. Tauris.

Thompson, Ewa. 200o. Trubadurzy imperium. Literatura rosyjska i kolonializm. Tłum. A. Sierszulska, Kraków: Universitas.

Tlostanova, Mladina. 2012. „Postsocialist $\neq$ Postcolonial? On Post-Soviet Imaginary and Global Coloniality Article”, fournal of Postcolonial Writing, nr 2.

Tomasik, Wojciech. 2016. Inżynieria dusz. Literatura realizmu socjalistycznego w planie „propagandy monumentalnej”. Toruń: Wydawnictwo Naukowe Uniwersytetu Mikołaja Kopernika.

Trotsky, Leon. History of the Russian Revolution, vol. 3, ed. C. Russel. b.m.w., https://www.marxists.org/archive/trotsky/works/download/hrr-vo 13.pdf (dostęp 16.06.2020).

Vaugham, James C. 1984. Soviet Socialist Realism: Origins and Theory. London: Palgrave Macmillan. 


\title{
Abstract, keywords, about the author
}

\begin{abstract}
The article describes the Soviet colonial project of the 1930s and the accompanying devices of knowledge/power. Based on the example of the socialist realist novel by Bruno Jasieński, Man Changes His Skin, the author analyses the hegemonic discourse of metropolis, focusing on issues such as the Soviet mission civilisatrice overrepresented in the novel, the genderization of the Russian's colonial dominance and the problem of ruling a subordinate territory by imposing the presence of an empire on the dominated area, i.e. displacing native symbols and appropriating and transforming local geography (cartography, architecture and urban planning) according to political interests of the empire.
\end{abstract}

Keywords: socialist realism, central asian studies, Bruno Jasieński, postcolonial studies, gender studies

Kasper Pfeifer was born in 1990; he is a Ph.D. candidate at the University of Silesia and is currently working on a research project on avant-garde and Futurism supported with a grant from the Polish National Science Center. His other interests include literature of protest and the revolutions of the nineteenth and twentieth centuries, people's history, and the philosophy of Jacques Rancière. He has published articles in several Polish magazines: 'Zagadnienia Rodzajów Literackich', 'Wielogłos', 'Praktyka Teoretyczna' and 'Teksty Drugie'. He is also the author of a poetry collection entitled adblock.

E-MAIL: pfeifer.kacper@gmail.com 